\title{
Illustration in Explanatory Dictionary
}

\author{
Dr. Asime Feraj \\ Vlorë, Albania \\ Dr. Arjan Llanaj Albania
}

\begin{abstract}
This paper has treated the syntagmatic level in the explanatory dictionaries, in the monolingual and bilingual as well, since the syntagmata in the dictionary can be dealt with as being unnoticed, because it is considered as less important than explanations or definitions or equivalents (when the dictionary is bilingual). But, if, for example, it can't be said in the explanation that a verb or adjective can be linked with words that refer to alive and not alive objects, than the user can see the illustrative examples (the weather became cold/cold (distant) from his friend; a cold room/a cold person; a man walks/ the horse walks; the time passes/ the work goes on; ecën koha (ecën puna). Nowadays, when the society is developing so fast and thoroughly, the use and utilisation of monolingual, bilingual, multilingual, linguistic or encyclopaedic dictionaries, is the most common and inevitable phenomenon, because these works not only are recorders of the word and phraseology, of semantic and lexical fortune, national and international one, but also have their determining importance in the acquirement of the language and in the expansion of the linguistic and communicative competence, in finding an unknown word and its semantic definition, or in finding lexical and semantic units with which creates semantic, paradigmatic, word-forming and stylistic relations etc. The illustrative examples are helpful for the full exploration of meaning and serve as an additional instrument for the characterisation of the word, showing the area of use and the typical grammatical lexicon enclosure. They also prove the stylistic evaluation and grammatical characteristic that is given to the word. The main purpose of this paper is that by relying in the subject that is offered by these kind of irreplaceable works, it will treat the importance of the syntagmatic level of the explanatory dictionary as an important part for knowing the word and its significance, to increase the lexical and semantic competence of the users of these dictionaries.
\end{abstract}

Keywords: dictionary, explanation of meaning, syntagmatic link, utterances, examples.

\section{Introduction}

The dictionary is a linguistic work that contains a large number of words, alphabetically listed, besides which are given explanations about lexical meanings (in the explanatory dictionaries) or corresponding words in foreign languages (in bilingual or multilingual dictionaries), and complementary frame words, necessary grammatical and stylistic notes, for the field that they are used, sayings, examples etc. Regarding the subject matter included in the dictionary they exploit the lexicon, synonyms, terminology, phraseology, toponymy, onomastics etc, and all the sources of written and spoken languages ${ }^{1}$.

Franz Jozef Hausmann defines the dictionary as a summary of the lexical units, which gives particular information for particular users and provides a quick and practical approach for each information ${ }^{2}$. Three important components are inferred on this: lexical information, the medium of presentation (which is related with the dictionary as a tool) and the user of this information which implies the user of the information.

${ }^{1}$ Fjalor i gjuhës së sotme shqipe, Tiranë, 1980, p. 481

$2 \mathrm{H}$. Shehu, Çështjetë sintagmatikës në fjalorë shpjegues të shqipes, in “Leksikografia shqipe, trashëgimi dhe perspektivë”, Tiranë, 2005, p. 161 
In the contemporary Albanian dictionary, the word dictionary (falor) is explained as a "book with the words of one language or with the terms of a particular field of science and technique etc, which are listed according to the alphabet and are explained and translated in another language or in several languages". There are many types of dictionaries. The explanatory dictionary (terminological, etymological, historical, encyclopedic). The orthographic dictionary, alphabetic dictionary, bilingual (multilingual) dictionary. The big dictionary (medium, small). The pocket dictionary. The dictionary of philosophy (of economy, physics, botanical, medicine). The dictionary of synonyms (of phraseology). ${ }^{1}$

There are many illustrative examples in dictionaries (saying and quotes) useful for full exposure of meaning and serve as complementary devices for the characterization of the word by showing the area of usage, the typical lexical and grammatical fields and prove the stylistic evaluation and grammatical peculiarity provided to the word. We deal with this aspect of the dictionary as the object of our project. The study of lexical and semantic subject matter, as well as of the sayings provided with examples, has made us to follow closely the alterations all around life in our country.

In the Albanian lexicon, several words go in or out. In other words, dictionaries are compositions that reflect these alterations and changes, and this is particularly visible during the compilation of new dictionaries in several periods of time. An evidence of such changes is the conduct of new meanings of one word, adapted to social- historical situations.

A national dictionary published in Congress of Orthography in 1972 has a normative character, because it reflects the lexicon and synonymic semantics of the standard Albanian. Nowadays, we are witnesses of many controversies regarding our literary language. The explanatory dictionaries, published in the last 30 years give a great contribution for setting the norm, therefore they are very much needed to the teachers, journalists, politicians, creators, not to say that they should be present in every Albanian family's library.

The national explanatory dictionaries provide examples not only from the depth of centuries, but also from all dialects and idiolects, that show the little distinctions we have on the lexical system, where there are more distinctions than in the other linguistic systems. At the same time, we notice the direct connection and interrelation between standard language and dialects and regional speech patterns.

Professor Haji Shehu, seeing the role of the phrases in a dictionary, emphasizes that "out of context and out of concrete conceptual personal belongings, the word provides indefinite information and has only potential meaning. It fully takes its real meaning, in other words it becomes a semantic unit in a given context or certain situation, where some of its meaning components are neutralized, and some others are actualized. In this aspect, the meaning is the result of the relation between the word and the sorrounding background". (see, e.g ; fog of doubt, heart of the earth, edge of the mountain (alb - shoulder of the mountain), an easy going person, dark room, dark thought, dark regime).

Compare: trim the apple (shartoj mollën) and shorten the socks (shartoj çorapet), the temperature got in 37 degree Celcius (të nxehtët mbërrit 37 shkallë) and the high ladder needs strong legs (shkalla e lartë do këmbë të forta), etc. If the words, got mad (u tërbua) , got crasy (u marros), got insane (u çmend) will not be put after the words "for her (pas saj)/for him (pas tij)" the meaning will not be "very keen on somebody or something", but the concrete meaning "lost his mind, logic or reason". In relational adjectives, the most attributive feature can be distinguished mainly depending on the context. Compare: for instance "silken dress and silken hair": 1. "soft as silk" and 2. "silky shine".

Particularly, the meanings of multiple -meaning verbs depend especially on the surrounding environment and the interrelation with nouns.

Compare: set the table for the lunch (shtroj dreken)/have a lunch for a special occasion (shtroj një drekë) / hospitalized his wife (shtroi të shoqen në spital) / opened a discussion (e shtroi për diskutim) / lay a broody hen (shtroi dy pula) / prepare pickled peppers and tomatoes (shtroi speca (domate), etc.

Between the internal content of the word (in these examples) and its usage in discourse, that is between its meaning and its apposition to the other word, there is an indispensible discursive connection in the phrase. This connection does not indicate ambiguity on the content of the word or as L.Vidgenstein says: "what can not be expressed in a sign, it is

1 J. Thomai, Leksikologjia e gjuhës shqipe, Tiranë, 2006, p. 315-316 
revealed in its usage". So, the lexicographer is obliged to indicate the content of the word without ambiguity, to mirror what is called the actualization of the lexical units ${ }^{1}$.

\section{The importance of illustration in the explanatory dictionaries}

The word has the ability to connect with other larger units as the phrase, the sentence, or the period, so, we must say that it has syntagmatic values. Every word that we select, in every meaning of it, creates some lexical-syntactic connections with other words, where it reveals the values of its content, the emotional and stylistic nuances, and also the phraseological connected meanings. So, dor/w-a $f$. (hand) is used in many relations to other words, such as: dora e djathtë (e majë) (right and left hand, i dha dorën - (shaked his hand to), prek me dorë, (touch with your hand), ka dorë - (has a handliterally; translated as "to beat and be violent"... The early ancient words and those that have many meanings have a wide range of lexical relations and have the possibility for new word combinations. Through these relations, it is fulfilled a lexical agreement, whereas, in the lexicographical work, they serve to explore the meanings of the word, the different stylistic and emotional nuances as well as the changes in form and content. Even the usage of the wide range of oral and written lexemantics is an expression of the richness of thought and language.

There are full and partial studies regarding the illustrations in an explanatory dictionary. We are considering one of the most prominent authors in our linguistics.

Prof. J.Thomai writes that "Syntagmatics in included at the illustrations of the dictionary, which are of two kinds: graphic (for example: photography, maps and drawings mainly in the encyclopedic and ideographic dictionaries) and linguistic (e.g statements (group of words), and full examples (sentences)." In the explanatory dictionaries we usually find illustrations of the second group.

a. Utterances, - according to him, - are short group of words, that are put after the explanation of one meaning, to fulfil it with subtle nuances and elements of that meaning, which cannot all be provided just in one explanation. But, utterances have other complementary values in the expressive, emotional and stylistic nuances, in the various kinds of syntactic relations of the word that is explained, in the lexical field and also in all its syntagmatics and lexemantics. Utterances show in this way that this word in this meaning is real in language and belongs to this particular field and has these particular features in usage. ${ }^{2}$

To illustrate, we are considering an example from the "Dictionary of the albanian language, 2006":

Bar,-i m.sh. - ëra(t) - (Eng. Grass) 1. A plant with a thin kërcell that doesn't become strong as the wood, with long and green leaves, that serves mainly as food for the animals; wet grass and hey; bad grass wild grass which damages the crops;

b. According to J.Thomai- "Examples serve to complement the explanation of meaning with semantic , emotional, expressive and stylistic, subtle nuances of usage etc. But more than phrases, they give a sense of beauty to expressions and vividness to various discourses. Examples come out from all genders of spoken and written language, from artistic, scientific and educational literature, from journalism, folklore, popular spoken discourses and so on. Based on this, proverbs have this function, too. They are well-chosen sentences, from writings of masters in language and linguistics, not only regular in grammatical construction, adaptable to the nature of Albanian language, but also from the aesthetic construction of expression, through which the reader acquires new values for the word and feels the strength and aesthetic importance of language." 3 Examples are associated with resources (such as author, writing, press, etc) in order to create certainty to the usage of the word in a given context. Examples usually are inserted in large explanatory dictionaries, but also, in medium-size dictionaries. With a marked and illustrative value at the same time could be even the linguistic phraseology, grouped in a particular meaning, when is connected on the essential elements of the meaning or at the end of the semantic structure of the word, after a specific sign (star or square).

For example; Alb - dal (exit) intrans. dola (exited) (past tense), dalë (participle)

1 J. Thomai, Leksikdogjia e gjuhës shqipe, Tiranë, 2006, p. 316

${ }^{2} \mathrm{H}$. Shehu, Çështjetë sintagmatikës në fjalorë të shqipes, in "Leksikografia shqipe, trashëgimi dhe perspektivë", Tiranë, 2005,

${ }^{3} \mathrm{H}$. Shehu, Çështjetë sintagmatikës në fjalorë të shqipes, in “Leksikografia shqipe, trashëgimi dhe perspektivë", Tiranë, 2005 
1. To go out from inside to the outside; to leave from some place and go some place else; left the house; to go out in the the world, to go for an outing;

Doli te burri (conversational) - got married; doli nga Traktati - went out from the Tractat;

V III springs (buron), flow (rrjedh), gush (vërshon), spreads (përhapet), leaves.

I dolën djersë (lotë) / sweat / tears went out of; doli naftë / the oil came out; doli nga tema / is irrelevant about the topic;

2. V III mbin (sprout), rritet diçka( something grows), shpërthen (explode), lind (is born), shfaqet (një sëmundje) (an illness appears)

3. Meet somebody; present oneself, be in front of, come across, show up somewhere; I doli përpara të birit (was in front of his son to meet with); I doli në ëndërr (it appeared in the dream); nuk i dal dot në sy dikujt (have a difficulty to be in front of somebodie's eye)

4. V III finishes, is lost, goes away, it doesn't exist anymore: doli dimri (the winter is finished); doli nga përdorimi (it can't be used anymore); I ka dalë nga qeji (nga zemra); (doesn't like it anymore); I doli frika (the fear went out); I doli nga mendja (forgot); I dolën të palarat (the cat went out of the bag)

c. Professor Haji Shehu by creating a new term of syntagmatics in the dictionary, the term examplification, emphasizes that examplification in a dictionary, the illustration of glossies by examples, the word joined to another word, is one of three lexicographical techniques, ( the others are: explanation in the wide sense of the word in lexicography, and equivalence in bilingual dictionaries). We deeply understand the value of illustration:

\section{Dictionaries do display the need of an ecological function, that is, the contextual interaction for the common interrelation of the words. ${ }^{1}$}

In scientific rather more encompassing outlook, he introduces his conceptual view over exemplification, when and how should be done this type of exemplification, for which lexical and semantic categories should be done, and how much volume should they occupy in semantic terms.

Theoretically, a relevant examination on "Syntagmatic issues in Albanian dictionaries, held in the conference. The Albanian Lexicography - a past inherited experience and a coming prospective, Tirana 2005 has constantly been one of the major theoretical sources of our research. In a further recapitulation weare introducing some notable arguments.

We are summarizing some of these arguments ${ }^{2}$ :

1. The lexical association of words from the logical relations that exist in the real activity between the objects and the phenomenon that is marked by the word (see for e.g : group of words that deal with the way people are categorized regarding physical and moral features: (it is said - she has a sweet mouth (gojë të ëmbël) and not (sweet teeth). This type of regularity might be called the law of valence and the lexicographer can't avoid these laws.

2.Valence is a potential interconnection of linguistic units, in other words a possibility to interconnect in the discourse according to the linguistic system. In the dictionary, the possibility becomes reality, the valence converts in a real unit interconnection. This means that valence (association) as a linguistic possibility and as an actualization reflects the dichotomy language-discourse, language-linguistic activity, (for example; good can have indefinite interconnections, but, in discourse in the meaning (i djathtë) - right can be connected only with hand/ foot/eye).

3. The word entirely acquires its real meaning by "being semantically involved in a context or a certain situation , where some of its components of meaning are neutralised and some others are updated. On this aspect, the meaning is a result of the interrelation of the word with the surrounding environment, (for e.g, fog of doubt, bulk of the earth , edge of the mountain, a good mixer (njeri i shkueshem), dark thought, etc. Between the internal content of the word and its usage in discourse, there is one indispensable connection in the word group, a connection that indicates

\footnotetext{
${ }^{1}$ A. Kostallari, Parimet themelore për hartimin e "Fjalorit të gjuhës së sotme shqipe" in "Studime mbi leksikun dhe mbi formimin e fjalëve në gjuhën shqipe", II, Tiranë, 1972, p. 45-47.

${ }^{2}$ Niepełnosprawność - zagadnienia, problemy, rozwiązania. $\mathrm{Nr} / / 2013(6)$
} 
which is the content of the word, or as L.Vitgenstein its usage ".

says, "that which cannot be expressed in the sign, appears in

4.'Phrases' deal with active-type dictionary. The lexico-semantic meaning is regarded as a system of its usage ( of linguistic contexts). Semantic possibilities of the word, appear not only to show the notion content, but primarily, by representing the whole typical distribution of a given word. (see, for example: (besa) loyalty is given, (kept, broken, returned) meanwhile, the duty can be (done, fulfilled, avoided); I have a fever (jam me ethe), is semantically different from I am anxious (jam në ethe)- in a figurative sense. , In the table (tryezën e bukës) we can eat food, while in the round table (tryezen ebisedimeve) we cannot. The constituent meaning of the word has a wide range of usages, depending on source of context, that reflect the word life in linguistics. These contexts go within word's semantics and have a proper usage. (compare : for example, comb my hair (kreh flokët) / comb the wool (kreh leshin), shorten the text (kreh tekstin) etc .

5. Phrases in a dictionary show what is possible or acceptable, because, as we know, there is a lexicographical law - the impossible or unacceptable frameworks and forms are not given in a dictionary. They serve to show the prescriptive, grammatical position, (as in; current/ electric light, electric squeezer/ electric egg-beater)

6. Syntagmas or sayings in a dictionary illustrate the grammatical behavior, (phonological, morphological and syntactical) of the word (for example, the type of the object :She wrote a letter and she wrote a letter to her brother, the type of the adjective : wide table I square table etc. It is the dictionary which has the obligation to do this, to give to the user vivid contexts, in order for him to understand the rules, as well as the semantic and grammatical principles of the words.

7. In the Albanian dictionaries, a special place is given to the reflecting of the popular lexicon with potential literary value (for known reasons) or even the creating of words with e potential literary value. The interconnection with other words of the language, shows them the way and the place to gain the real literary value status, because the uncertainty of the meaning/meanings is lessened a lot. (të vdjerrët / euph. "të vdekurit" (the dead)

This is also one of the reasons that these kind of words are presented with expressions, and, at the same time, it is one of the values that is brought by not only the national Albanian dictionaries, but also by the dictionaries with popular words and expressions from the regions. For the syntagmatics in a lexicographic work, it has also been written by Proff. Androkli Kostallari. Although he speaks about the essential principles for the design of "The Dictionary of today's Albanian language", thus, about the principles of the reflection of the illustrations covering a specified work, they have a great value for each Albanian language dictionary.

d. We are presenting a general summary of these principles according to prof. Androkli Kostallari. ${ }^{1}$

1. Definitions of meanings and semantic variety of words are associated regularly and are verified with illustrative material (quotations and sayings). With the term utterance, we understand the typical illustrating examples that have a wide use in our time, and are compiled by the designers and editors of "the dictionary" based on materials of "Record section of the vocabulary of the Albanian language", as well as of their own precise knowledge of self experience.

2.The illustrative examples help the exploration of a complete understanding and serve as a complementary tool for the characterization of the lexeme, showing the sphere of its use, the typical lexico-grammatical associations, verifying the stylistic and the grammatical characteristic given to the word. To this general principle, it should be subjected even the phraseology, when it can perform such functions.

\section{Conclusions}

\footnotetext{
${ }^{1}$ Regulation of Minister of Infrastructure of 12 April 2002 on the technical conditions which must be met by buildings and their location, Journal of Law s, 2002, No 75 item 690, as subsequently amended; Regulation of Minister of Infrastructure on the technical conditions which must be met by buildings and their location. Journal of Laws, 2011, № 144, item 859, as subsequently amended; The Construction Law of 7 July 1994 Journal of Laws of 2016, item 2255; Kowalski K. Mieszkanie dostępne dla osóbz dysfunkcjami w zroku; Biblioteka dla Osób Niepełnosprawnych, www.integrcja.pl; NowakE., Budny J., Kowalski K. Mieszkanie dostępne dla osób z dysfunkcją narządu ruchu; Biblioteka dla Osób Niepehosprawnych, www.integrcja. pl; Kowalski K. Planowanie dostępności - prawo w praktyce; Biblioteka dla Osób Niepełnosprawnych, www.integrcja.pl;
} 
The word has the ability to group with other words in larger units, such as: the phrase and the sentence. Through these connections, a linguistic agreement is created. Prof.Haji Shehu, by defining a new term for the syntagmatics in a dictionary, the term- examplification emphasizes that : dictionaries need the ecology of the words, that is, contextual interrelations, for the usual interrelations of the words.

Utterances show that the word in this sense is real in the language and has this field and features of use, while the examples serve to complement the explanation of the meaning with subtle semantic, exciting, expressive, stylistic nuances of the usage etc, but, more than utterances, they give the beauty of the expressions with the words that are used, its vividness in different discourses.

They are well selected sentences from the writings of masters of language, as regular not only in the linguistic construction, in accordance with the nature of the Albanian language, but also in content and "aesthetics" of expression, through which the reader gains new values for the word and feels the beauty and the strength of language. Examples are associated with their source to create a sense of security in the use of the word in a given context.

Since the dictionaries are irreplaceable works in school, we have tried to have in mind even our work as a teachers of language and literature. And syntagmatics has a multiple function in this regard.

We believe that this paper can be addressed to the post -graduate students, to the teacher of the Albanian language in school, the researcher, the lexicographer, the interpreter, the journalist, the creator of literary and finally to the citizens, who are associated with the Albanian word, with valence and its multiple links, diverse and implicated with other words, directly or indirectly, in one form or another, in a discourse or another, in one style or another, in the synchronic plane or the diachronic plane.

\section{Bibliografi}

[1] A. Kostallari, Parimet themelore për hartimin e "Fjalorit të gjuhës së sotme shqipe" in "Studime mbi leksikun dhe mbi formimin e fjalëve në gjuhën shqipe", II, Tiranë, 1972

[2] 12 Fjalor $i$ gjuhës së sotme shqipe, Tiranë, 1980

[3] 3 H. J. Franz, Lexikographie, Königstein, 1985

[4] ${ }^{4} \mathrm{H}$. Shehu, Çështje të sintagmatikës në fjalorë shpjegues të shqipes, in "Leksikografia shqipe, trashëgimi dhe perspektivë", Tiranë, 2005

[5] 5 J. Thomai, Leksikologjia e gjuhës shqipe, Tiranë, 2006

\footnotetext{
${ }^{1}$ It is w orth clarifying, at this point, that although the Resolutions of the UN General Assembly are part of what is commonly known as softlaw, in this particular case, and because it is a directive or resolution necessary to comply with contents agreed in International Treaties of Human Rights that do hav e a binding nature (hardlaw), this Resolution must be understood with sufficient force and obligation to bind the States that are part of the Treaties that are referred in it. In addition, this binding nature is also due to the very content of the Resolution, which, by incorporating the expression of General Principles applicable to international law, and by condensing international obligations of States in accordance with common law, endows Resolution of a mandatory qualification, specifically for the Colombian State (Colombian Commission of Jurists, 2007, p.22). 